cilia, naked discally, excepting for a pair of isolated cilia in a line longitudinally, central and somewhat proximad of the middle between the apex of the venation and the apex of the blade. Antennal club dusky. Cephalic face of the pronotum black. Hind femora sometimes dusky. Scape and legs nearly white.

The male is similarly coloured.

Described from a large number of specimens of both sexes reared from the eggs of Hilda breviceps Stal, Los Banos, Philippine Islands, February, 1915, C. F. Baker.

Types.-Catalogue No. 19300 , U. S. N. M., four males, four females on a slide. A large number of paratypes on another slide.

\title{
A NEW SPECIES OF PSEUDOMPHALE FROM CHILE.
} BY A. A. GIRAULT,

Bureau of Entamology, U. S. Dept. Agriculture.

The genus Pseudomphale Schrottky is the same as Horismenus in the North American sense. It may be Horismenus in the European sense, yet doubtfully. There are three ring-joints. The single Australian species of Horismenus represents a new genus which may be named Horismenopsis, new genus. The genotype is Horismenus antiopa Girault. The following new species of Horismenus was found in the collections of the United States National Museum when reviewing the North American Entedoninæ.

1. Pseudomphale hypatia, new species.

Female.-Length, $2.50 \mathrm{~mm}$.

Differs from lixivorus Crawford in that the tibixe are not dark, but merely embrowned centrally or brown except at tips; the stripe of scaliness across near apex of segment 2 of the abdomen is not so wide nor so produced proximad at lateral margin, the petiole is distinctly shorter and vertical, the abdomen subsessile, the median carina of the propodeum longer and broader. From floridanus Ashmead in the same particulars except the tibia, which are darker than in that species, brown, not white; also in foridanus, segment 2 of the abdomen is longer, slightly over half the length of that region (somewhat less than half in this new species); also the thorax is blue, not black. Differs from microgaster Ashmead in the shorter segment 2 of the abdomen. Runs close to brasiliensis Ashmead, but differs in the shorter abdominal

July, 191. 
petiole, shorter segment 2 of the abdomen, which in brasiliensis occupies $3 / 4$ of the surface and is sculptured broadly distad, the median carina of the propodeum is broarder and the pedicel longer, the tibiæ darker being brown. Compared with types of the named species except microgaster. Three ring-joints. Pedicel slightly longer than funicle 1 .

Differs from the genotype in its dark femora, scape, etc. Described from three females labelled "Ceroplastus novaesci, Santiago, Chile, M. J. Rivera, Letter March 15, 1910."

Types.-Catalogue No.19320, U.S. N. M., two females on tags (one a paratype). Parapsidal furrows half complete from caudad. Median groove of scutum delicate, only at proximal third.

ErratA.-In my article "Geometrid Notes" in the Canadian Entomologist, Vol. XLVII No. 5, pp. 155-158, I wish to make the following corrections:-

P. 157, line 24, for "paratype" read "paratypes".

P. 157, line 28, for "saawichata" read "saanichata".

P. 158, line 29, for "fuscata" read "furcata".

P. 158, line 34, for "saawichata" read "saanichata".

L. W. SwetT.

BOOK REVIEW.

Key to the Families of North American Insects.-An Introduction to the Classification of Insects. By Charles T. Brues, Assistant Professor of Economic Entomology, Harvard University, and A. L. Melander, Professor of Entomology, State College of Washington, Boston, Mass., and Pullman, Wash. Published by the Authors, 1915. 137 pp., 18 plates.

This little book brings together a complete analytical key to the orders and families of North American insects compiled from the works of the most recent authorities in the various branches of systematic entomology. Such a work has been a great desideratum among teachers of entomology in view of the rapid changes in the classification of insects which have been brought about in recent. years as a result of the labours of an ever-increasing army of workers in this field.

The book "has been prepared to meet the requirements not alone of college courses in systematic entomology, but also of 